\title{
DISCOVER CHILDREN'S PASSIONS AND ENVIRONMENTAL RESPECT THROUGH MANAGEMENT OF ECO LIFE SKILLS LEARNING
}

\author{
Dwi Rahmah Hidayati \\ Department of Educational Management \\ State University of Malang, Indonesia \\ dwirahmah.h@gmail.com
}

\author{
Agus Timan \\ Department of Educational Management \\ State University of Malang, Indonesia \\ gus26timan@gmail.com
}

\author{
Desi Eri Kusumaningrum \\ Department of Educational Management \\ State University of Malang, Indonesia \\ desi.eri.fip@um.ac.id
}

\begin{abstract}
Teachers and educational policy makers with interest in the children's welfare are in position to lay strong foundation for sustainable living in world crises, nowadays. To do this, teachers in Sanggar Flamboyan Muharto Malang City have been developing Eco Life Skills Learning Programme for primary age children. It facilitates the children to characterize their passions and extend environmental education. Effective management of Eco Life Skills Learning by the teachers is the key to reach successful children's achievements. Therefore, the aims of this research is to be understood about management of Eco Life Skills Learning, include: planning, organizing, implementing, and evaluating. Qualitative method with case studies is the study design. Data collected by observation, interviews, and documentation. Then, analyzed by data reducation, data display, verification, and conclusion. The result showed: (1) management of Eco Life Skills Learning in Sanggar Flamboyan Muharto Malang City has a goal to accompany children's development and invite changing the environment to be better, the planning begins with stimulates children about the environmental conditions around them through story telling and direct observation; (2) the organizing had integrated 11 aspects of Eco Life Skills into 7 categories of learning activities engaged with their mothers participations; (3) the implementing had applied direct learning and problem based learning models, with discussion and cooperative methods as dominant; (4) the teachers had used informal and formal techniques of evaluating, analyze: (a) children's passionate activities; (b) attitudes; (c) skills; (d) activity concentration (motivation, attendance, and participation).
\end{abstract}

Keywords: management of learning; eco life skills; passion and environmental respect; education for sustainable development

\section{INTRODUCTION}

Sanggar Flamboyan Muharto Malang City is one of the learning centers for children age 7-12 years old and their mothers on the type of community based education in the region of Muharto Gang V. That was established by The Children and Social Welfare Organization Harapan Ummat (LKSA HARUM). Ensure a sustainable world for the good of present and future generations is an urgent responsibility in all sectors, nowadays.

Started at January 2015, the teachers in Sanggar Flamboyan Muharto Malang City have been developing Eco Life Skills Learning Programme. It facilitates the children to characterize their passions and extend environmental education. Moreover, the programme are adaptive and put high attention on the values, attitudes, and skills [1].

In such a way that every child will meets the talent and environmental respect as his or her everyday life's habit. Management of Eco Life Skills Learning in Sanggar Flamboyan Muharto Malang City has an opportunity to expand education for sustainable development in schools, home education, and communities based education. If every child is able to discover his or her passion and do eco-friendly, sustainable living in this world will be created. Children's involvement are deserve for sustainable living development because of several reasons. The following theories are described clearly.

\section{A. Children at Primary Schools Age}

Children at primary schools age (7-12 years old) reach a concrete operational stage of development. In this phase, all children have a need to know the universe as the focus of their development [2]. This opinion supported by Fitrah Based Education concept, Harry Santosa [3] make clear that every child has fitrah to learn and think, aesthetic fitrah and language, faith and divine fitrah, talent and leadership fitrah, and sexuality.

To build up them, particularly fitrah to learn and think is by allowing the children, particularly at 7 10 years old to have good interaction with universe. This way could facilitate the children to recognize their mission of life as Rahmatan lil 'Alamin (Compassionate with Universe). Growing as innovator in this world, so the children reach their purpose of life as Khalifatullah fil Ardh (Man of God), and earn God blessing.

Furthermore, the result of research by Kevin Lynch about "The Children's Perception of the Environment" at 1971-1975 indicates that one of the best environment for children is a community that provides the opportunity for them to study and investigate the environment and their world [4]. Because of the basic needs of children's development, fitrah, and children's perception of the environment, it is important to facilitates the children at primary age to have good interaction with Universe. 


\section{B. Passion of Children}

Passion is a strong feeling of enthusiasm or excitement for something or about doing something [5]. Passion is a source of interest and unique to each individual. It can not be forced. Passion is the greatest gift of self-discovery. Gray [5] said that it is important to allowing the children plenty of time to explore without pressure or limits. That time is needed to make friends, play with ideas and materials, experience and overcome boredom, learn from one's own mistakes, and develop passions. So, to help the children discover their passion, it is really important for parents or teachers to give the children plenty of time to explore without pressure.

\section{Environmental Respect for Children}

Environmental respect is one of the strethening character education values designed by Ministry of Education and Culture of Indonesia at 2011. Environmental respect defines as: (1) attitudes and actions that are always working to prevent the damage to the surrounding natural environment, and (2) developing effort to repair the damage that has already occurred [6].

\section{Management of Learning}

Management of Learning in units of Education Beyond School (PLS) is the process of planning, implementing, and evaluating the interaction of student learning activities and tutor for achieving the student's learning objectives [7]. Based on the experts opinion, there are four main functions in management of learning, namely: (1) planning; (2) organizing; (3) implementing; and (4) evaluating.

Irianto [7] defines planning of learning as a process of preparing a series of decisions to reach the goal. Organizing according to Triwiyanto [8] is a process of a curriculum and learning organizing with activity of designing structures, analyzing subject matter and the qualification, classify and share the main of the subject matter in each line, level, and type of education. Implementing of learning based Suprihatiningrum [9] is a way of performing or presenting, describing, leading, and practice giving content to the students to achieve a particular goal. The implementation of study consist of three main activities, namely introduction, core (exploration, elaboration, confirmation), and the end.

Implementation of learning can use spesific learning model. Arends [10] said that models of learning leads to a certain learning approach which includes the purpose, syntax, environment, and management systems. There are several innovative learning models in 2013 curriculum (Kurikulum 2013) based Shoimin [11], such as contextual teaching and learning, cooperative learning, direct instruction, dramatic learning, inquiry, problem based learning, role playing, and outbound.

According to Suyono and Hariyanto [12] there is continuity in a model of learning includes a learning approach, learning strategies, learning methods, and techniques of learning. There are examples of the learning approach, environmental approach, contextual, heuristics, concepts, process skills, inductive, deductive, and others. Examples of learning methods include speech, ask and answer, discussion, task, project, and cooperative learning. There are two principal of learning strategies, teacher centered and student centered. The examples of learning techniques are inquiry, speech, discussion, presentations, role playing, study tour, and others.

Evaluating of learning based Basuki and Hariyanto [13] is "a systematic and continuous process to gather information about the success of student's learning and useful for improving the effectiveness of learning". Churchill, Ferguson, Godinho, Johnson, Keddie, Letts, Mackay, McGill, Moss, Nagel, Nicholson, Vick, divide the evaluation of learning into two categories, there are informal and formal. Informal evaluation can be done through class discussion, group interaction, and respond to the question or the work of students. Formal evaluation conducted through summative or final semester at the end of the school year [14].

According to Basuki and Hariyanto [13] there are some class based evaluation, for examples are written test, attitude test, evaluation of project, evaluation of product, portfolio, and others. There are strategies of non test evaluation as an important way, namely class presentation, conferences, demonstrations, interviews, and observation. Formal evalution of learning, often done by teachers in the form of report. The contents of the report submitted to the parents, school, and states with different contents for each other [14].

\section{E. Eco Life Skills Learning Programme and Education for Sustainable Development}

Life Skills become one of the basic human ability is taught in the schools. According to the United Nation International Children's Emergency Fund (UNICEF) (2003), Life Skills is an ability of the psychosocial and positive behaviors that can effectively use someone adapt the demands and the challenges faced in everyday life [15]. The implementation of life skills education according Kosasih, do not need to create new subjects, but by giving the charges on each subject with material that can provide certain capabilities to students that can be applied in everyday life. General description of theme material for elementary school are friendship, adventure, game, and the natural environment [16].

Environmental education could be learned from Ecology. Ecology is the science that studies the interactions between living beings and living creatures with their surroundings. Today, Ecology became a key science contribute to solving major global humanity [17]. In addition, there is the concept of Eco Life that invites human beings contribute to solve the problems of the environment and the Earth. It is related with approach to early childhood education for sustainability agenda that participates the children. Its believe children as active citizens and the orientation to them is vital to avert the crises of sustainability. It is possible because young children deserve, to be engaged in learning, decision making and action taking 
in their schools, homes, and communities on topics pivotal to their wellbeing in the present and future [18].

The combination concept of Life Skills, Ecology, and Eco Life produce formulations Eco Life Skills. Eco Life Skills is a learning program to accompany the children discover their passions and build up their inside environmental respect. With the result that they meet passion, be creative, happier, healthier, and more productive live.

There are 11 aspects of Eco Life Skills with modification [15].

1. Self Awareness; recognition of ourselves, character, strengths and weakness, desires and dislikes.

2. Emphaty; ability to imagine what life is like for another person, understand and accept others who may be very different from ourselves, or to tolerance.

3. Interpersonal Relationship; to relate in positive ways with people we interact with (keep friendly relationship).

4. Effective Communication; able to express ourselves, both verbally and non-verbally, in ways that are appropriate to our cultures and situations.

5. Critical Thinking; ability to analyse information and experiences in an objective manner.

6. Creative Thinking; to explore the available alternatives and various consequences of our actions or non-actions.

7. Decision Making; to deal constructively with decisions about our lives.

8. Problem Solving; enables us to deal constructively with problems in our lives.

9. Coping with Stress; recognising the sources of stress in our lives, recognising this effects us, and acting in ways that help to control our levels of stress.

10. Coping with Emotions; recognising emotions in ourselves and others, being aware of how emotions influence behaviour, and being able to respond to emotions appropriately.

11. Eco-friendly actions; participates to reduce, reuse and recycle (3R), prevent environmental damage, and solve environmental damage that has already occured.

\section{METHODS}

Management of Eco Life Skills Learning research had done through a qualitative approach to the type of case studies research. The studies had conducted from June 2015 to August 2016 continuously and descriptive.

Researcher became full participant with requested permission to The Chairman of LKSA HARUM, M. Noor Choirullah and The Teachers of Sanggar Flamboyan Muharto Malang City, Nurul Istiqomah and Kasianah.

\section{A. Locations}

There are three locations of the research:

1. Sanggar Flamboyan Muharto Malang City (Children and Mother's Learning Center) in Hall of Muharto Gang V RW 09;

2. The Trash Bank of Malang (BSM), Supriyadi Street Number 38A Subdistrict of Sukun, City of Malang;

3. The office of LKSA HARUM, on the Candi Panggung Street Number 01, City of Malang.

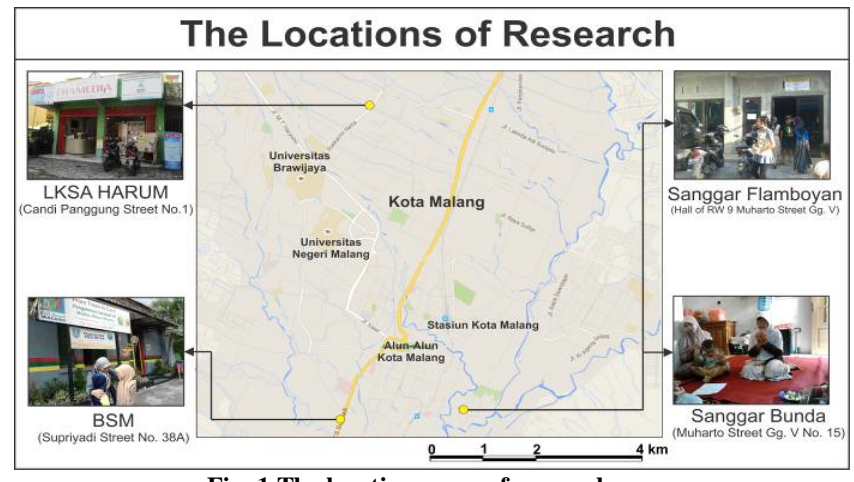

Fig. 1 The locations map of research

Researcher had participated in the learning activities of Sanggar Flamboyan Muharto Malang City every Sunday 09.00-11.00 am, learning of waste management in the Trash Bank of Malang (BSM) on Friday at 14.00-16.00 am, and collected administrative data on Thursday or Saturday in the office of LKSA HARUM.

\section{B. Data Resources}

The sample data source selected by purposive and snowball sampling. Through purposive technique definable that Nurul Istiqomah as key informant. The researcher obtained the main data about the form of activities on every function management of Eco Life Skills Learning by snowball sampling.

\section{Data Collection}

The researcher collected data through observation, interviews, and documentation. Complete participation is the way of this research participation technique. The researcher became the teacher in Sanggar Flamboyan Muharto Malang City at 2015 and Coordinator of Teachers in LKSA HARUM at 2016. The researcher had written the observations on fieldnotes. Then, collected data through interviews had carried out with several informants. 
Table 1

\begin{tabular}{cllcc}
\multicolumn{6}{c}{ Informants and the details of interview for management of eco life skills learning } \\
\hline No. & \multicolumn{1}{c}{ Informants } & \multicolumn{1}{c}{ Date } & Total & Frequency \\
\hline 1 & The students & 17\&19 June 2016 & 5 & 1 \\
2 & The teachers & 22 July and 01 August 2016 & 2 & 1 \\
3 & Coordinator of Mother's Center & 22 June 2016 & 1 & 1 \\
\hline
\end{tabular}

Moreover, observation and interviews data were fitting combination with documentation data. The document find the result of attitudes scale test, learning portfolio, children development report, company profile of LKSA HARUM, and others.
Furthermore, data had given a code (coding) based on the focus of the research. Similar data collected is classified to be indentified.

Table 2

Data collection code

\begin{tabular}{clcclc}
\hline \multicolumn{1}{c}{ Description } & Code & No. & \multicolumn{1}{c}{ Description } & Code \\
\hline No. & \multicolumn{1}{c}{ Data collection code } \\
\hline 1. & Data collection technique & & 3. & Name of Informant & \\
a. & Observation & O & a. & Zulfa Auliya & ZU \\
b. & Interviews & W & b. & Nova M. & NV \\
c. & Documentation & D & c. & Husnol Hisom & HU \\
d. & Number of fieldnote & $001,002, .$. & d. & Andi Rindan & AD \\
2. & Focus of Research & & e. & Izaatun Nafisa & NF \\
a. & Planning & F1 & f. & Abyz Wigati & AB \\
b. & Organizing & F2 & a. & Zulfa Auliya & ZU \\
c. & Implementing & F3 & g. & Nurul Istiqomah & IS \\
d. & Evaluating & F4 & h. & Kasianah & AN \\
\hline
\end{tabular}

These are the methods of writing fieldnotes and interviews transcript.

a. Observation data: the technique of data collection/ number of fieldnotes/ focus of research/ date of research. Example: O/001/F3.01/0906-2015.

b. Interviews data: the technique of data collection/ code of informant's name/ focus of research/ date of interviews. Example: W/ZU/001/F4.01/17-06-2016.

\section{Data Analysis}

Data analyzed by data reducation, data display, verification, and conclusion. The researcher reduce data based the most related and important data to focus of research. Then, display data through short description, flowchart, and pictures. Next, The researcher checked the validity of data by triangulation, member check, and deep observations. Member checked by handing back a transcript of the interviews to be read by informant. If the data that researcher write is correct, the informant can give a signature. List of informants in process of member check on Table 3.

Table 3

List of Informants and Date of Member Check

\begin{tabular}{|c|c|c|c|}
\hline No. & $\begin{array}{l}\text { Name of } \\
\text { Informants }\end{array}$ & Function & $\begin{array}{c}\text { Date of Member } \\
\text { Check }\end{array}$ \\
\hline 1. & Nurul Istiqomah & Chief of Teacher in Sanggar Flamboyan Muharto Malang City & 28 July 2016 \\
\hline 2. & Kasianah & Teacher of Sanggar Flamboyan Muharto Malang City & 04 August 2016 \\
\hline 3. & Zulfa Aulia & Children of Sanggar Flamboyan & 07 August 2016 \\
\hline 4. & Nova Margareta & Children of Sanggar Flamboyan & 07 August 2016 \\
\hline 5 . & Husnol Hisom & Children of Sanggar Flamboyan & 07 August 2016 \\
\hline 6. & Andi Rindan & Children of Sanggar Flamboyan & 07 August 2016 \\
\hline 7. & Izzatun Nafisa & Children of Sanggar Flamboyan & 07 August 2016 \\
\hline 8. & Abyz Wigati & Chief of children's parents in LKSA HARUM & 28 July 2016 \\
\hline
\end{tabular}

The Researcher, 2016

Last, the researcher give the conclusion of research. The conclusion form is short description.

\section{RESULT}

\section{A. Planning of Eco Life Skills Learning}

The teachers in Sanggar Flamboyan Muharto Malang City have been taking the children's involvement on all process of learning, include the planning function. Based on observation on 06 September 2015, the teachers had stimulated the children about the conditions of their community environment. The teachers had applied story telling and direct observation methods to discover the children's interest and sensitivity for the environment. That is described in the following fieldnote.
On Sunday, 06 September 2015 at 09.00-11.00 am there is an activity to observe the river polution occured around Muharto community. An activity started with praying together and learning introducing from the teachers. The teacher says that she will telling the story to the children. She asks the children to go to river in north of Sanggar Flamboyan Muharto. In the river, the teacher was preparing storytelling media when the children took their own comfort sit down positions. Firly and Nafisa participate to operating the media as a fish and flower (O/008/F3.01/06-09-2015).

The teachers had been collecting the children's ideas when they designed lesson plan. It is 
based on interview with The Chief of Teacher Sanggar Flamboyan Muharto, Nurul Istiqomah. She said that, "Before we did our learning activities, we should stimulate the children about the environment conditions. We consider the children's response and ideas. So, the ideas of learning activities not only from teachers but also children's perspective. Then, we facilitate the children's ideas and implementing together. Such as, they want to clean the river, actually the teacher has plan to learning other materials, sometimes we bring into line of the children's really want" (W/IS/004/F1.01-02/22-07-2016).

There is one of the examples of children's ideas of learning activities.

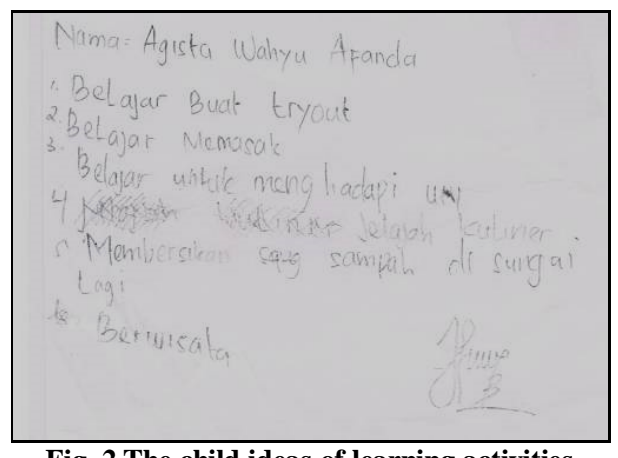

Fig. 2 The child ideas of learning activities

The teachers consider the children's ideas and put into the annual plan of learning activities Sanggar Flamboyan Muharto Malang City. The teachers presented the annual plan in front of teachers in LKSA HARUM. They discussed and offered several addition or advises.

\section{B. Organizing of Eco Life Skills Learning}

There are 18 children in Sanggar Flamboyan Muharto Malang City that on age 8-11 years old. The teachers engaged the children's learning to their mothers. For example, there is same activity between children and mother's learning center, had made crafts from recycled materials.

To make sure the programme was running well, it is important to be understood the children and families background, phase of children development and level of education.

Table 4

Children and mothers names and ages

\begin{tabular}{|c|l|c|c|l|c|}
\hline No. & \multicolumn{1}{|c|}{ Name } & $\begin{array}{c}\text { Age } \\
\text { (vears old) }\end{array}$ & Grade & $\begin{array}{c}\text { Mother's } \\
\text { name }\end{array}$ & $\begin{array}{c}\text { Age } \\
\text { (years old) }\end{array}$ \\
\hline 1 & Abdul Qodir & 10 & IV & Salama & - \\
\hline 2 & Agista Wahyu Afanda & 11 & VI & Wahyuti & - \\
\hline 3 & Ajeng Anggi A & 11 & V & Marwati & - \\
\hline 4 & Andi Rindan & 11 & V & Sumiati & - \\
\hline 5 & Ani Fitria & 11 & III & Sulimah & 46 \\
\hline 6 & Arsya Putra P & 8 & III & Hesti & - \\
\hline 7 & Eka Wulandari & 8 & III & Latifah & 27 \\
\hline 8 & Firlya El Azkya & 8 & III & Sri Wigaty & 45 \\
\hline 9 & Husnol Hisom Maulana & 10 & IV & Hormatun & - \\
\hline 10 & Izzatun Nafisa & 10 & IV & Choiriyah & 30 \\
\hline 11 & Musrifin & 9 & IV & Asrimah & 30 \\
\hline 12 & Nailatul Husna & 8 & II & Juma'iyah & 28 \\
\hline 13 & Nova M & 9 & V & Ita Pujianah & 32 \\
\hline 14 & Prima Restu Aji & 11 & VI & Satunah & - \\
\hline 15 & Safira Della Vita & 11 & VI & Silah & - \\
\hline 16 & Firda Siti Rohmah & 11 & V & Hasunah & - \\
\hline 17 & Zulfa Auliya & 11 & VI & Rosidah & - \\
\hline 18 & Khusnul Khotimah & 8 & III & Subaidah & 41 \\
\hline
\end{tabular}

The Researcher, 2016

The children were learning together in the same activities although they have different ages. They were classified based on school grades if they were learning in academic lesson. The teacher of Sanggar Flamboyan Muharto, Kasianah said that when they were learning other academic lesson, the teachers gave the general lesson and everyting around their daily living (W/AN/005/F2.04/01-08-2016).

The whole learning materials is life skills. Eco Life Skills was adopted by the teachers for the children based on the children's needs and environmental problems and conditions in Muharto, Malang. There are 11 aspects of Eco Life Skills were growing up into the children, namely: self awareness; emphaty, interpersonal relationship, effective communication, critcal thinking, creative thinking, decision making, problem solving, coping with stress; coping with emotions, and taking environmental friendly actions. All aspects have been integrating into 7 categories of learning activities in Sanggar Flamboyan Muharto, namely: academic, home visit, talents and interests, clean the river, study tour, cooking and give additional food nutritively, and non academic.

To describe more clearly, this is the following picture for an example of kinds activities. 


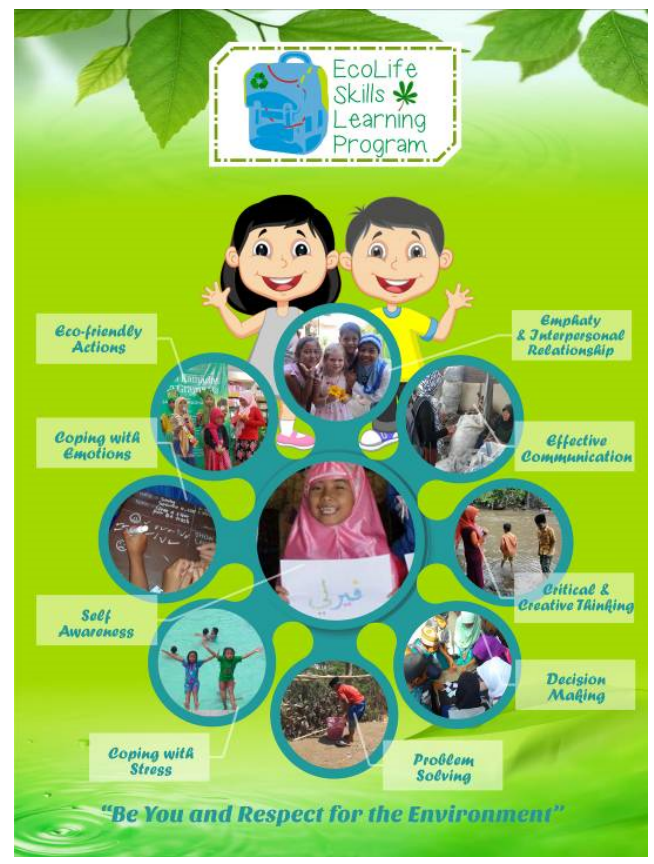

Fig. 3 Integrated aspects of Eco Life Skills Learning in Sanggar Flamboyan Muharto Malang City

The picture figures out that several aspects of Eco Life Skills are filling in an activity. Moreover, all aspects are unity.

\section{Implementing of Eco Life Skills Learning}

Implementing of Eco Life Skills in Sanggar Flamboyan Muharto Malang City has been handling as a team teaching. There are 2 teachers, Nurul Istiqomah and Kasianah. They were implementing Eco Life Skills Learning through highly varied learning activities. Until, the materials is the hidden curriculum and integrated with other lesson. The example of implementing Eco Life Skills Learning is described by Nurul Istiqomah and the picture before (Figure 3).

The children are making "kolase" from recycled things, such as used paper, used fabric, or seconds bottles. Sometimes, they made brooch from seconds bottles. That shows us about creative thinking and eco-friendly actions aspects from the children. They also warned others whose sent the trash into the river or mistakenly, although they are adults. That is such an emphaty aspect of the children. When they interviewed their neighbourhood about their habits of waste management, they learned how to have interpersonal relationship and effective communication
(W/IS/004/F2.03-04/22-07-2016).

There are several effective activities of Eco Life Skills Learning in Sanggar Flamboyan Muharto Malang City.

1. Study tour to Eco Green Park Batu Malang

2. Waste management learning

3. River observation

4. Clean the river

5. Make environmental campaign posters

6. Adventuring to save the river

7. Reading eco-friendly stories books, such as: Sahabat Bumi, Kisah Kota Kita, Komik Muslim Cilik, Aku Sayang Ibu, and others

8. Self Awareness activities such as: make genogram, learn body parts, and all about family

9. Recycle activities: make crafts

10. Kidpreneur Festival: selling the recycled goods made by the children

11. Children's Performance Day, namely “Pesta Karya Anak Flamboyan" and Kids Festival. The children show up themselves based on their interests, talents, or passions.

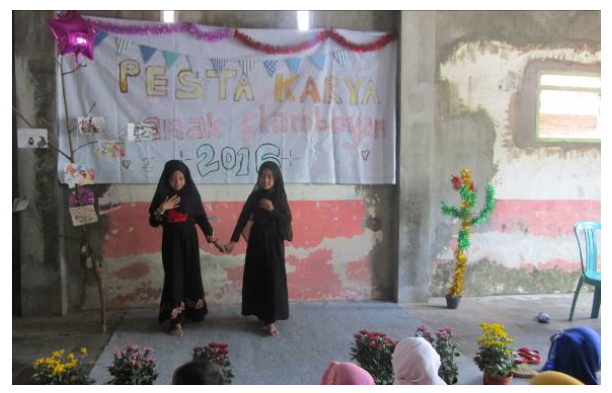

Fig. 4 The Children were dancing together because they love dancing 
The teachers had used 9 teaching and learning models, namely: inquiry, direct learning, role play, problem based learning, project based learning, outbound, cooperative, contextual, and drama. In particular, there are problem based learning and direct learning as dominants. Then, 10 teaching and learning methods had used by the teachers, namely: cooperative, question and answer, lecturing, discuss, storytelling, observation, reflection, presentation, project, and task. The dominants are cooperative and discussion methods. Kasianah said that with discussion, teachers could teaching the children less observably (W/AN/005/F3.03/01-08-2016).

\section{Evaluating of Eco Life Skills Learning}

The teachers in Sanggar Flamboyan Muharto Malang City had evaluated the learning in all process. In the beginning of learning, the teachers had visited the children's homes to be understood the background and real conditions of the children and their families.

In process of learning, the teachers had self observed to evaluated the children. The observed aspects are attitudes, creativity, and skills
(W/IS/004/F4.06/22-07-2016). The teachers appreciated the children's achievements such as the children would have been titled as "The Little Hero of Environment" if they brought their trash from homes to distributed in Trash Bank of Malang, gave them the stickers, blue ribbon as Hero, and gifts.

Other evaluating techniques are written test, presentation, portfolio, attitudes scale test, monthly meeting evaluation, exhibition, and children's development reports. Attitude scale test had researched by Mrs. Abyz Wigati as the Chief of children's parents in LKSA HARUM at 2016. The result shows the differences of environmental respect levels of the children who getting Eco Life Skills Learning Programme and not facilitated yet.

The average of children environmental respect in Sanggar Flamboyan Muharto Malang City achieve 78,967 that there is "meaningful differences" between children in another sanggar of LKSA HARUM which did not facilitated Eco Life Skills Learning Programme, the average is 54,343 . The result noted in the figure 5 .

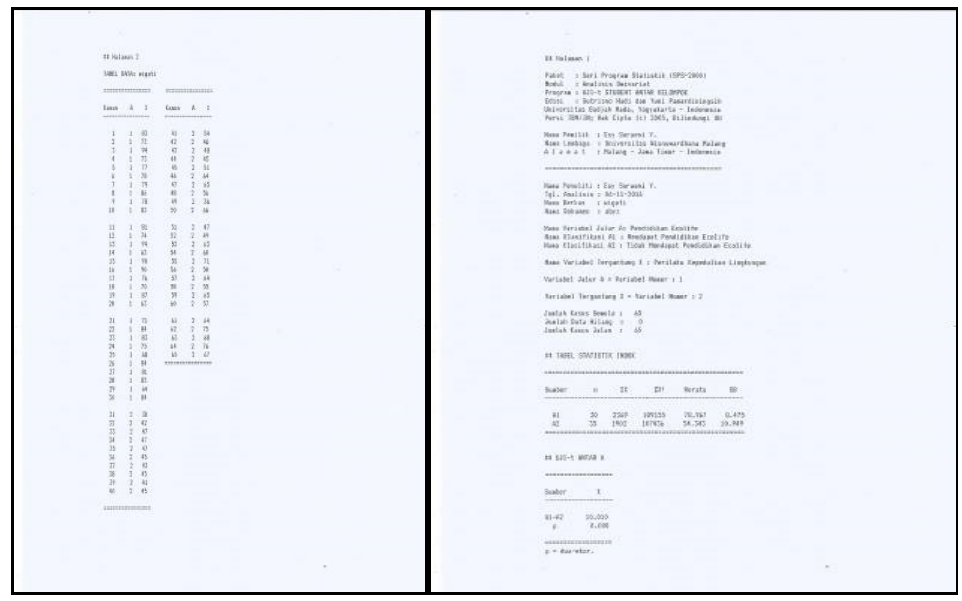

Fig. 5 The Result of attitudes scale test of children environmental respect in LKSA HARUM (Sanggar Flamboyan Muharto compared with Sanggar Tholibul Haq Lowokwaru, and Sanggar Cenderawasih Gadang)

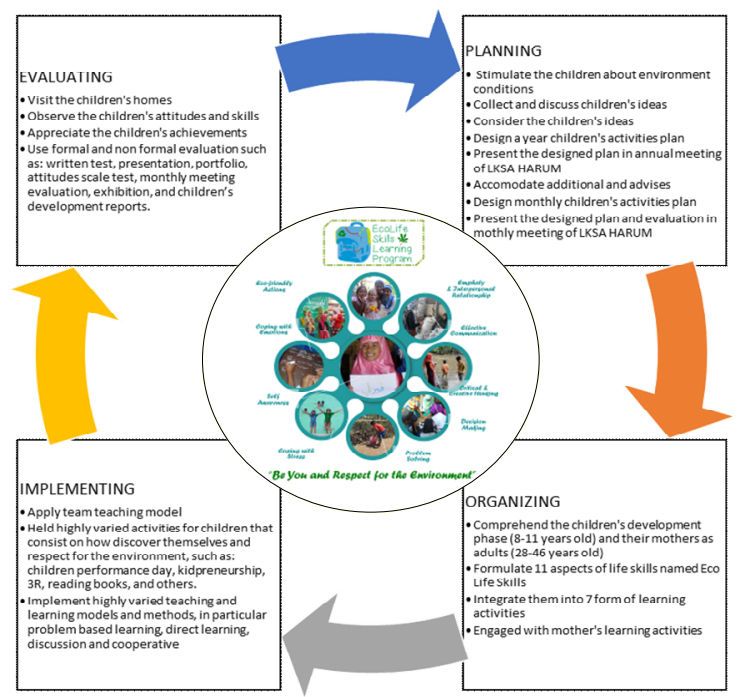

Fig. 6 Management of Eco Life Skills in Sanggar Flamboyan Muharto Malang City 


\section{E. Management of Eco Life Skills Learning}

Based on research data, Management of Eco Life Skills Learning in Sanggar Flamboyan Muharto Malang City has a goal to accompany the children's development and changing the environment to be better. The motto of learning is "Be You and Respect for the Environment". The teachers want the children able to discover their interests and talents that represented their passions and taking eco-friendly actions in their everyday life.

The management of Eco Life Skills Learning in Sanggar Flamboyan Muharto is in the following of figure 6. The picture shows that activities on every functions management are connected and influence each other. There are 19 activities in management of Eco Life Skills Learning had applied in Sanggar Flamboyan Muharto Malang City.

\section{Discussion \\ A. Planning of Eco Life Skills Learning}

Everychild has different goal of learning. Actually, in a class or group of learning it does not easy to facilitates everychild wants and goal perfectly. Give chance to the children share their ideas of learning activities before design the curriculum or implementing the learning programme is such a good way to accomodate everychild wants and goal. Combine them with the main objectives of learning based on children's development, fitrah, and this challenging world era also needed. These are the decisions have to consider by the teachers on planning of learning. That is similar with Irianto's opinion[7] because planning as a process of preparing a series of decisions to reach the goal.

The essential goal of Eco Life Skills Learning is accompany the children discover their passions and extend environmental education. To had combined with the children's goal, on 06 September 2015, the teachers had stimulated the children about their environment conditions that the river has been poluting by trash. The teachers had tried to build up the children's environmental respect through direct observation and storytelling. Direct observation is an effective method because the children were watching and feeling with the environment directly. It is a good way to turn in with the environment. The children are easier to be influenced and connected with nature environment because like Armstrong and Harry Santosa that at primary schools age, particularly 7-10 years old the children have a need to know and have good interaction with Universe.

Moreover, storytelling is a good choice of methods too, because based on Wilson research [18] storytelling can enhance the connection that children have to the environment. Stories of local places are used as a teaching tool to inform and inspire, and to elicit an emotional response to the local environment. Both of methods proven to be effective. The children had shared their ideas about learning activities they wants and ideas to solve the poluted river. One of the ideas is clean the river from the trash, noted on Figure 2.
To accompany the children discover their passions, the teachers have to consider and facilitate the children's interests and talents wisely. In addition, the goal of learning by teachers and children could in a line.

\section{B. Organizing of Eco Life Skills Learning}

According Triwiyanto ${ }^{[8]}$ organizing is a process that the teacher designing structures, subject matters and qualifications in each line, level, and type of education. In general, the concept of Eco Life Skills is need clear materials and qualifications in each level of Eco Life Skills Learning. The peak of achievements is everychild meets her or his passion and acts ecofriendly. Therefore, the teachers could classified the level of Eco Life Skills children's achievements based them sides.

Passion[5] is a strong feeling of enthusiasm or excitement for something or about doing something. The teachers need to classified the level and qualifications of passion such as level of consistency the children feeling or doing something, type of activities, and their enhancement related their passions. Besides of it, the teachers could organized the level and qualifications of eco-friendly acts such as level of consistency the children act eco-friendly, kinds of actions, and level of role (as follower, problem solver, or innovator).

Communicate and engage this concept to the children's parents is an effective way because they could strengthening characterise Eco Life Skills into the children. The learning could running well not only in Sanggar Flamboyan Muharto but also in their home and society.

\section{Implementing of Eco Life Skills Learning}

The teachers in Sanggar Flamboyan Muharto Malang City have been designing, leading, and examplizing Eco Life Skills Learning. This role related with Suprihatiningrum's opinion[9] that implementing is a way of performing, leading and practice giving content to the students to achieve a particular goal.

There are 2 models of learning used by the teachers to achieve the particular goal, namely direct learning and problem based learning. Direct Learning is suitable with the particular goal because to discover the children's passions, both of children and teachers need long time, procedural and structural process[11]. Furthermore, problem based learning is effective to help the children getting involved to solve their environmental problems in Muharto community. This model practice and gained skills of the children to solve the authentic problems on their everyday life. With the result that, the children proven to be part of problem solvers in their community. They had participated on waste management programme in Sanggar Flamboyan Muharto, members of Trash Bank of Malang, clean the poluted river, made recycled crafts and others. The following picture shows the children's contribution solve their poluted river in Muharto. 


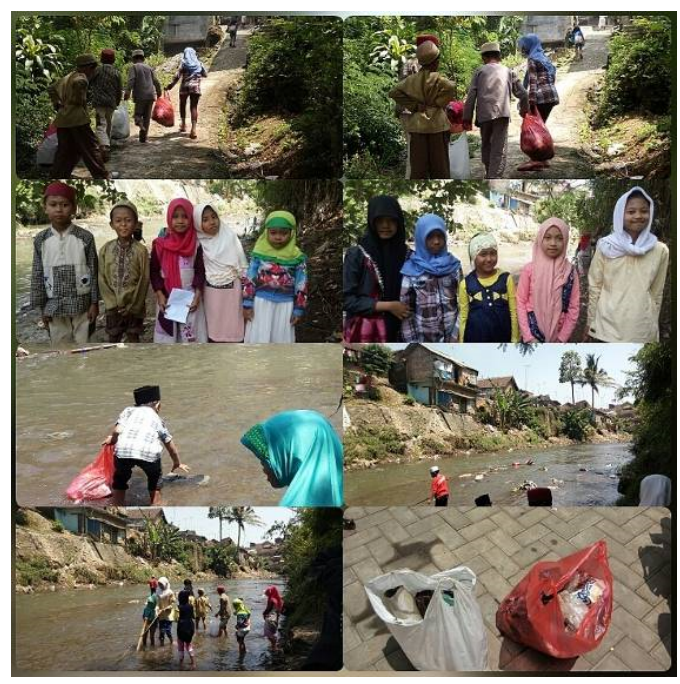

Fig. 7 The children act eco-friendly by clean the poluted river

\section{Evaluating of Eco Life Skills Learning}

Evaluated aspects of Eco Life Skills Learning are attitudes, skills, and activity concentration (motivation, attendance, and participation). It is be in mutual accord the goal of Eco Life Skills that focus on strengthening character to be what children themselves and respect for the environment. Attitudes and skills are foundation to faced the challenging life.

Evaluating of learning based Basuki and Hariyanto [13] is "a systematic and continuous process to gather information about the success of student's learning and useful for improving the effectiveness of learning". One of the effective evaluating in the beginning process of learning to gather information about the teacher is home visit. Visited the children's homes could work out closer relationship between the teachers, children, and their parents. The teachers understood the children's background, needs and motivations for learning in Sanggar Flamboyan Muharto Malang City.

\section{E. Management of Eco Life Skills Learning}

Ki Hajar Dewantara[19] defines the goal of education is guides fitrah of the children as human being and society to reach the highest happiness. Management of Eco Life Skills learning is one of appropriate ways related the goal of education. The peak goal of Eco Life Skills Learning is the children meet their passions and act eco-friendly. This achievement could make the children's live balance as human being, society and part of Universe.

\section{CONCLUSION}

The world sustainability crises nowdays is needed the contribution from all sectors, include education field. The teachers is one of the essential powers to build up strong foundation of sustainable living in this world. The teachers could teaching Eco Life Skills Learning Programme to the children in primary schools age (7-12 years old). The learning programme accompany the children discover their passions and extend environmental education. The children have to be themselves and act eco-friendly.
For example, the children have passionate to dancing, they would became dancer who do not throw the trash mistakenly, dancer who used recycled accessories or costums, and others.

To reach the goal, effective management of Eco Life Skills Learning have to connected every fuctions with all following activities. There are some important activities have to applying: (1) stimulate the children about their environment; (2) collect and discuss the children's ideas; (3) combine the children's ideas of learning activities and the goal of Eco Life Skills Learning; (4) classified the level and qualifications of passion and eco-friendly acts for the children; (5)communicate and engage Eco Life Skills Learning to children's parents; (6) Use highly varied learning models and methods; and (7) observe the children's performances, in particular are children's passionate activities, attitudes, skills, and activity concentration (motivation, attendance, and participation).

This programme need improvement continuously to accompany the children's development. The teachers necessary to create blueprint or best practice of Eco Life Skills Learning. Several points should included on blueprint are: background, the goal, vision, mission, kinds of activitites, subject matters, level, process, and achievement's qualifications of Eco Life Skills Learning.

\section{ACKNOWLEDGEMENT}

Sustainable Development for present and future generations is our responsibilities. Thanks for all: Team of LKSA HARUM, Lecturers, Children in Sanggar Flamboyan Muharto Malang City, and Parent. Thanks for this chance, time for research and presentations.

\section{REFERENCES}

[1] Rahmah, Dwi Hidayati, "Management of Eco Life Skills Learning; Case Studies in Sanggar Flamboyan Malang City", Minithesis, Department of Educational 
Administration, Faculty of Education, State University of Malang, 2016.

[2] Armstrong, Thomas, "The Best Schools: Mendidik Siswa menjadi Insan Seutuhnya", Bandung: Kaifa, 2011, pp. 151.

[3] Santosa, Harry, "Fitrah Based Education Framework",

[4] Purwoko, Krisman, "Kota di Indonesia Belum Layak Anak", (Online), (http://www.republika.co.id/berita/shortlink/103530) 2010.

[5] Newman, Susan, "How to Support and Nurture Your Child's Passion; Advice from 'The Happy Kid Handbook' Author", (Online), (https://www.psychologytoday.com/blog/singletons/201 510/how-support-and-nurture-your-childs-passions), October 2015

[6] Sumardiono, "18 Nilai dalam Pendidikan Karakter Bangsa", (Online), (http://rumahinspirasi.com/18-nilaidalam-pendidikan-karakter-bangsa/), 2011.

[7] Irianto, Yoyon Bahtiar, "Manajemen Pembelajaran Dalam Konteks Pendidikan Luar Sekolah", (Online), (http://file.upi.edu/Direktori/FIP/JUR._ADMINISTRAS I_PENDIDIKAN/196210011991021YOYON_BAHTIAR_IRIANTO/Manaj-KBM-pls.pdf), March 2016.

[8] Triwiyanto, Teguh, "Manajemen Kurikulum dan Pembelajaran", Jakarta: Bumi Aksara, 2015, pp. 152.

[9] Suprihatiningrum, Jamil, "Strategi Pembelajaran", Jogjakarta: Ar-Ruzz Media, 2013, pp. 118.
[10] Trianto, "Desain Pengembangan Pembelajaran Tematik Bagi Anak Usia Dini TK/RA \& Anak Usia Awal SD/MI", Jakarta: Kencana, 2011, pp. 142.

[11] Shoimin, Aris, "68 Model Pembelajaran Inovatif dalam Kurikulum 2013”, Yogyakarta: Ar-Ruzz Media.

[12] Suyono, and Hariyanto, "Belajar dan Pembelajaran", Bandung: PT Remaja Rosdakarya Offset, 2012.

[13] Basuki, and Hariyanto, "Asesmen Pembelajaran", Bandung: PT Remaja Rosdakarya, 2015, pp. 18.

[14] Churchill, Ferguson, Godinho, Johnson, Keddie, Letts, Mackay, McGill, Moss, Nagel, Nicholson, Vick, "Teaching Making A Different", Australia: John Wiley \& Sons Australia, Ltd, 2013, pp. 215-216.

[15] United Nations International Children's Emergency Fund (UNICEF), "Life Skills", (Online), (www.unicef.org), November 2015.

[16] Kosasih, "Strategi Belajar dan Pembelajaran Implementasi Kurikulum 2013", Bandung: Yrama Widya, 2015, pp. 40.

[17] Bodini, Antonio., Klotz, Stefan, "The Science of Ecology for a Sustainable World", (Online), on Encyclopedia of Life Support System (EOLSS) (http://www.eolss.net/eolss-sampleallchapter.aspx), July 2016.

[18] Wilson, Carla., "Effective Approaches to Connect Children with Nature", Department of Conservation: New Zealand, 2011.

[19] Dewantara, Ki Hajar, "Karya Ki Hajar Dewantara", Majelis Luhur Persatuan Taman Siswa: Yogyakarta, 1977. 